\title{
INTERNATIONAL LAW AND INTERNATIONAL RELATIONS
}

\author{
DOI: 10.46340/eppd.2021.8.5.1
}

\author{
Anastasiia Siabro \\ ORCID ID: https://orcid.org/0000-0001-8051-5191 \\ Taras Shevchenko National University of Kyiv, Ukraine \\ THE INFLUENCE OF SCIENTIFIC \\ AND TECHNOLOGICAL DEVELOPMENT \\ ON THE TRANSFORMATION OF THE GLOBAL \\ SECURITY PARADIGM
}

The article considers the urgent problem of the impact of information and scientific and technological changes on the transformation of the modern security paradigm. In particular, the study examines the contradictory consequences of the introduction of the Fourth Industrial Revolution technologies, the dual nature of the use of modern technologies, which not only opens new opportunities for progressive development of the world, but also significantly affects the modernization of security challenges and threats at global, regional and national levels. Possibilities of illegal use of such technologies as "digital vision", implantable technologies, additive production, artificial intelligence, unmanned aerial vehicles, robotics, space-based systems by "unfriendly" states, terrorists and criminal groups or individuals are briefly characterized. The tendencies of technological modernization of threats of a purely military nature, which occurs as a result of the intensification of the global geopolitical confrontation, are also analyzed. In particular, it is shown that today there is a tendency to increase the level of conflict in the world, which leads to a new arms race and the militarization of technological and scientific advances. Currently, countries are rapidly trying to increase military capacity, including through information and technological modernization. This does not only lead to the development of the arms market, but also threatens the problem of getting new weapons into the hands of "unfriendly" countries or terrorists and criminal groups. The article concludes that in the face of new challenges and threats to the security system at the global, regional and national levels, it is extremely important to transform the security paradigm, which should contribute to the further progress of the world.

Keywords: security paradigm, Fourth industrial revolution, information security, information weapons, artificial intelligence, robotics, additive production, implantable technologies, modernization of the armed forces, arms market.

Introduction. Powerful developments in science and technology lead to gradual changes in all spheres of modern society. At the same time, these developments have led to the transformation of challenges and threats to the global and national security system, which has put on the agenda the transformation of the security paradigm and the need to develop new approaches in this area. The results of information and scientific and technological development are now actively used by states to increase military power and modernize weapons, which significantly changes the nature of wars and conflicts. It should also be noted that this problem was significantly affected by the COVID-19 pandemic, which, on the one hand, accelerated digitalization processes, further developed both traditional and new types of information business, rapidly upgraded software, significantly changed approaches to logistics, and on the other hand, the scale of cybercrime has increased, and the methods of criminal activity in the digital space have improved. Another important consequence of the pandemic is the threat of digital dictatorship and the application of mechanisms of restricting human rights and freedoms through the introduction of electronic means to prevent the spread of the disease and monitor compliance with the rules of self-isolation of citizens. Thus, the problem of developing a new security paradigm becomes an extremely important issue for all actors in international relations. 
Information and scientific and technological development has influenced the emergence of new types of challenges and threats that have an asymmetric nature of action and cannot be effectively neutralized by traditional mechanisms formed within the previous security paradigm. The growing number of information wars and conflicts, the implementation of hybrid warfare strategies against the background of a constant increasing of the number of users of global networks and services, the modern technologies connected to the global information infrastructure, necessitate a revision of approaches to the modern security environment and a new security paradigm which takes into account world development trends.

Thus, the main purpose of the article is to analyze the factors influencing the transformation of the modern security paradigm in the context of accelerated information and scientific and technological development of the world.

The main text. Information and scientific and technological development of countries and regions of the world opens new opportunities for the introduction of better models of economic development and public administration, as well as leads to large-scale social change. The Internet of Things, additive manufacturing, artificial intelligence, unmanned vehicles and robotics - all these innovations can significantly affect the further progress of the world. At the same time, this can lead to powerful negative consequences, as the availability and widespread dissemination of information and scientific and technological developments makes the security system vulnerable and leads to new types of challenges and threats.

New opportunities and new threats began to be discussed in the middle of the XX century as part of the formation of the concept of the information society. Even then, the authors noted that the emergence of new information technologies and further scientific and technological development will have both positive and negative consequences for human development. But since the 1990s, when the problem of building an information society has become one of the priority strategies of global development, it has become clear that not only new opportunities for progressive development but also new challenges and threats have emerged, leading to a rethinking of security approaches both the global and national levels. Changing the nature of conflicts, increasing the number of asymmetric wars and conflicts, facilitating access to more powerful weapons, growing threats of terrorism and extremism, conflicting motives and relatively chaotic organization of the parties to the conflict - all these trends have become possible due to the concept of information civilization, significant expansion of access to modern information and scientific and technological resources, which led to the need to revise the existing security paradigm ${ }^{1}$.

The emergence of new technologies in the framework of the Fourth Industrial Revolution has significantly accelerated the process of transformation of the security paradigm. The transformations that began to be talked about in Germany in 2011 as a new stage of the industrial revolution, in 2016 and 2018 were finally presented as a new concept of industrial development in the reports of K. Schwab's "Fourth Industrial Revolution" and "Forming the fourth industrial revolution". Thus, among the main "cientific and technological "chiev"ments were identified miniaturization of"computers and continuous digitalization, implantable technologies, digital presence technologies, gadgets with interactive interface, "digital vision", portable Internet, Internet of Things and for things, connected houses, "smart" cities, unmanned vehicles, artificial intelligence, robotics, additive manufacturing, bitcoins and blockchain, genetic engineering, neurotechnology, etc. These technologies, according to the author, have a significant potential for social, economic and political changes, open opportunities for the introduction of new models of economic activity, raising standards in social security, providing services, including medical and educational, new approaches to development and implementation political strategies, decision-making, etc. At the same time, the possibility of using the outlined technological innovations for illegal purposes is worrying, as almost all of them have dual-purpose and can be used, for example, to increase the army's combat capability and improve the armaments of outsider states or "failed" states that support or finance terrorist grouping or contributing to large-scale terrorist attacks by both organized groups and "individuals"3.

\footnotetext{
${ }^{1}$ European Commission (2021). Changing security paradigm <https://knowledge4policy.ec.europa.eu/changingsecurity-paradigm_en> (2021, September, 18).

${ }^{2}$ Шваб, К. (2019). Четверта промислова революиія. Формуючи четверту промислову революиію. Харків: КСД.

${ }^{3}$ Ibid, 101-141.
} 
For example, implantable and digital vision technologies can be used to interfere with privacy, identity theft or disabling electronic identification systems ${ }^{1}$. Additive production technologies can be used to produce weapons that are difficult to identify and prevent its illegal use. 3D printing is also used for the production of chemical, biological and nuclear weapons, for creation of details for the fuel systems of nuclear reactors, missiles and warheads. In combination with artificial intelligence or nanotechnology, additive technologies can become even more dangerous ${ }^{2}$. According to experts, the potential for the use of such innovations can turn into a kind of "black swan", if used as part of the military strategy of the state aimed at strengthening military capabilities ${ }^{3}$.

Unmanned aerial vehicles are now used not only for intelligence purposes, communication or transferring of medicine, but also for identification of targets, delivering of ammunition or striking ${ }^{4}$. Artificial intelligence technologies are actively used to improve these means of confrontation, which significantly increases their combat effectiveness. Artificial intelligence is also used to create "smart materials", which allows to achieve greater success in reducing the visibility of samples of military and special equipment and increases the efficiency of intelligence, such as the use of "Stealth". Nowadays advances in quantum cryptography are becoming more and more important, which not only enables the secure transmission of information, but also creates new problems related to intelligence collection ${ }^{6}$.

The world's leading armies are already equipped with a variety of systems that use autonomous robotics (such as turret robots on a moving platform) to search or even destroy targets, which significantly enhances the striking power of military units. Currently, experts do not have a single opinion on the use of robotics in the military sphere. First, the legitimacy of robots being classified as humane weapons remains unresolved, as autonomous weapons systems, once activated, can select and hit targets without further human intervention, and the ability to program artificial intelligence robots to comply with international humanitarian $\mathrm{law}^{7}$. Secondly, the use of autonomous military systems has not acquired a final international legal form, and therefore they can be used uncontrollably by both states and terrorist groups, which will lead to a violation of the balance of power in world geopolitics. Third, the production of such systems becomes simpler and cheaper due to the spread of three-dimensional printing technologies. Fourth, it is difficult to identify the source of the threat of using such technologies, which makes it impossible to identify the initiator and bring him to justice (for example, in the current conflict in Syria, a drone attack on a Russian-Syrian base, the source of which has not been officially identified $)^{8}$.

\footnotetext{
${ }^{1}$ Шваб, К. (2019). Четверта промислова революиія. Формуючи четверту промислову революиію. Харків: КСД, 102; Charles, А. (2013). Google Glass: is it a threat to our privacy? Guardian <https://www.theguardian.com/technology/2013/mar/06/google-glass-threat-to-our-privacy> (2017, September, 18); Корелина, О. (2018). В Китае создают тотальную систему распознавания лиц граждан. Она поможет ловить преступников и собирать данные на всех остальных. Meduza <https://meduza.io/feature/2018/02/11/v-kitae-sozdayuttotalnuyu-sistemu-raspoznavaniya-lits-grazhdan-ona-pomozhet-lovit-prestupnikov-i-sobirat-dannye-na-vseh-ostalnyh> (2021, September, 18).

${ }^{2}$ Fernandez, E. (2019). Soon, People May Be Able To Use 3D Printers To Build Weapons Of Mass Destruction Forbes <https://www.forbes.com/sites/fernandezelizabeth/2019/09/17/soon-people-may-be-able-to-use-3d-printersto-build-weapons-of-mass-destruction/?sh=12dfb0ee6c92> (2021, September, 19).

${ }^{3}$ Christopher, D., Christopher, G., Dalnoki-Veress, F., Pomper, M., Shaw, R. (2019). WMD Capabilities Enabled by Additive Manufacturing. NDS Report 1908. James Martin Center for Nonproliferation Studies <https://www.nonproliferation.org/wp-content/uploads/2019/09/NDS_Report_1908_WMD_AM_2019.pdf> (2021, September,19).

${ }^{4}$ BBC (2012). Drones: What are they and how do they work? <https://www.bbc.com/news/world-south-asia-10713898> (2021, September, 19).

${ }^{5}$ Изюмов, Д. Б., Кондратюк, Е. Л., Гренчихин, А. В., Логунов, А. Б. (2018) Использование искусственного интеллекта в вопросах обеспечения национальной безопасности США. Инноватика и экспертиза, 3 (24), 169.

${ }^{6}$ Chen, S. (2017). Chinese Satellite Relays a Quantum Signal Between Cities. WIRED

<https://www.wired.com/story/chinese-satellite-relays-a-quantum-signal-between-cities/> (2021, September, 19).

${ }^{7}$ Department of Defense (2012). Autonomy in Weapon Systems. Directive. Number 3000.09 <https://www.hsdl.org/?view\&did=726163> (2021, September, 19); Walsh, T. (2019). A.I. Expert, Is Racing to Stop the Killer Robots. The New York Times <https://www.nytimes.com/2019/07/30/science/autonomous-weaponsartificial-intelligence.html?auth=link-dismiss-google1tap> (2021, September, 19).

${ }^{8}$ Walsh, T. (2019). A.I. Expert, Is Racing to Stop the Killer Robots. The New York Times

<https://www.nytimes.com/2019/07/30/science/autonomous-weapons-artificial-intelligence.html?auth=link-dismissgoogle1tap> (2021, September, 19).
} 
The growing number of Internet users and people who regularly use various devices of Internet of things in everyday life, has led to further actualization of the problem of cybersecurity and resilience of networks to various attacks. This makes the information infrastructure extremely vulnerable, especially in the context of connecting critical energy facilities, transport management or medical services, which can lead not only to technical or software failures, but also to real human casualties ${ }^{1}$.

Space-based systems, which now provide communication and global surveillance, can also be critically vulnerable to cyberattacks. As these systems are cyberphysical, cyber-attacks can not only lose or damage important data, disrupt satellites, and have a direct impact on the physical world (for example, used as a kinetic weapon to hit other elements of space infrastructure $)^{2}$. The situation can be complicated by the fact that implementation of such an attack does not require significant resources, cyberattacks can be carried out by private groups or individuals. Thus, there is a situation where a state or non-state entity that does not have internal cyber capabilities can potentially pose a threat to the cyberspace of countries and regions of the world ${ }^{3}$.

Thus, the rapid information and scientific and technological development is one of the most important factors in the transformation of the modern security paradigm. At the same time, the dual nature of the use of scientific and technological progress has an ambiguous impact on geopolitical rivalry, turning scientific achievements into a powerful weapon that can destabilize the international system of peacekeeping and security ${ }^{4}$. According to the Report of the World Economic Forum "Global Risks" (2020), 5G networks, quantum technologies and artificial intelligence are becoming a major challenge for the security system, as they can be used to build military capabilities or to improve methods of warfare ${ }^{5}$. The main challenges for progressive global development of the world have been identified in the document. They are cyber risk fragmentation and destruction of information infrastructure as well as deepening the digital divide, which today leads to increased distrust of technological advances and negative perceptions of scientific and technological development. Of concern is the fact that in the absence of an effective management system for scientific and technological development with the constant growth of technology penetration into all spheres of society, this can lead not only to aggravation of geopolitical confrontation, but also to increasing the consequences of cyber weapons, as technology penetration in the physical world forms the so-called cyberphysical systems ${ }^{6}$.

It should be noted that the problem of the dual nature of the use of scientific and technological achievements has long been discussed by UN experts in the formation of the international legal framework of the global system of peace and security. Since the late 90's of the twentieth century issues of the impact of scientific and technological development on international security were constantly discussed at the UN General Assembly. The result of the discussions was the adoption of resolutions "The role of science and technology in the context of international security and disarmament" and "Developments in the field of information and telecommunications in the context of international security", which are reviewed and supplemented every year ${ }^{7}$. At the same time, experts and representatives of the governments of UN member states failed to develop a common position on the principles of international information security, modern information weapons and the dual nature of the use of information and scientific and technological developments, as well as the convention on international information security. So, despite the desire of states to develop common standards of conduct in the global information space in order to reduce the probability of using the results of scientific progress to destroy the global security environment,

\footnotetext{
${ }^{1}$ European Commission (2021). Changing security paradigm <https://knowledge4policy.ec.europa.eu/changingsecurity-paradigm_en> (2021, September, 19).

${ }^{2}$ Ibid.

${ }^{3}$ Harrison, T., Johnson, K., Roberts, T.G. (2019). Space Threat Assessment 2019. A Report of The CSIS Aerospace Security Project. The Aerospace Security Project <https://aerospace.csis.org/wp-content/uploads/2019/04/

SpaceThreatAssessment2019-compressed.pdf>, 5. (2021, September, 19).

${ }^{4}$ World Economic Forum (2020). Global Risks Report $2020<$ http://www3.weforum.org/>, 61. (2021, September, 16).

${ }^{5}$ Ibid, 62.

${ }^{6}$ Ibid, 63.

${ }^{7}$ United Nations (2021). Developments in the field of information and telecommunications in the context of international security <https://www.un.org/disarmament/ict-security/> (2021, September, 16); UN. General Assembly (1999).

Role of science and technology in the context of international security and disarmament

<https://digitallibrary.un.org/record/399865> (2021, September, 19).
} 
the issue remains unresolved and needs further consideration. Thus, the lack of effective mechanisms for international legal regulation of various aspects of information security leads to further escalation of global geopolitical tensions and improvement of means of warfare.

Rapid scientific and technological developments have also affected other challenges and threats to the global, regional and national security system, significantly enhancing their impact. Therefore, the issue of transformation of the security paradigm in the context of the formation of digital civilization should be considered as a set of problems that may not be directly related to technology itself, but can be significantly exacerbated by them. For example, the formation of the modern security environment is significantly influenced by the growth of non-military factors of socio-economic and resource-environmental nature. But in the context of growing global geopolitical tensions, the most pressing issues remain purely military which in the conditions of inefficiency of mechanisms of the international legal regulation of development and use of modern scientific and technological innovations can lead to further deepening confrontation between various actors in international relations.

For example, among the general factors of a military nature that influence the change of the security paradigm, experts identify the trend of constant growth of conflict in the world community, increasing military power, which leads to a change in the balance of power in modern international relations, increasing global arms market activities and acts of civil disobedience. According to analytical studies of the Global Peace Index for 2019 and 2020, although there is a tendency in the world to reduce the total number of cross-border conflicts, but the scale of their consequences for the regional and global security system is growing significantly. Therefore, the world community seeks to pay more attention to conflict prevention and preventive action to identify potential sources of tension and confrontation. The reports also note that the number of more peaceful countries is constantly increasing, but so is the number of less peaceful ones. At the same time, the gap between them in the basic indicators of socio-economic and political development is growing. The number of victims of direct hostilities, terrorist attacks or extremist actions is also increasing, leading to an increase in uncontrolled migration and an increase in the number of refugees ${ }^{1}$.

Within the existing conflicts, the information component is gradually increasing, which may increase the effect of destructive influence on the enemy, forming a new dimension of confrontation - informational or hybrid (for example, in the conflicts between India and Pakistan, Israel and Palestine or Ukraine and Russia). At the same time, as noted in the Global Terrorism Index 2020, the conflicts remain the main driving force of terrorist activity in the countries most affected by this phenomenon, such as Afghanistan, Nigeria, Syria, Somalia, Yemen, etc ${ }^{2}$. Of course, the situation in different countries may differ significantly, but the trend is still global and can significantly influence the political decisions of governments and international institutions in the field of security.

With the constant increase in the number of internal conflicts involving paramilitary groups and the scale of extremist activities, the process preventing terrorist acts is significantly complicated, but does not lose its relevance. Terrorist activities are significantly modernized by increasing access to modern weapons, including cyber or biological weapons, which in turn leads to an increase in losses from their use for terrorist purposes. According to experts, these types of weapons, which can easily fall into the hands of terrorists, criminals or so-called "individuals", are extremely difficult to identify, and therefore the security system becomes more vulnerable, which in turn leads to the need to review existing mechanisms to counter challenges and threats at both the national and global levels ${ }^{3}$.

The emergence of new forms of terrorist financing, such as the use of charities or fake companies, crowdsourcing, online payments and cryptocurrencies, also plays an important role in the growth of terrorist activity. According to RAND experts, today terrorist and criminal groups are actively using

\footnotetext{
${ }^{1}$ Institute for Economics \& Peace (2019). Global Peace Index 2019 Measuring Peace In A Complex World <https://www.visionofhumanity.org/wp-content/uploads/2020/10/GPI-2019web.pdf> (2021, September,20); Global Peace Index 2020. Measuring Peace In A Complex World (Institute for Economics \& Peace) https://www.visionofhumanity.org/wp-content/uploads/2020/10/GPI_2020_web.pdf> (2021, September,20). ${ }^{2}$ Institute for Economics \& Peace (2020). Global Terrorism Index 2020: The ten countries most impacted by terrorism $<$ https://www.visionofhumanity.org/global-terrorism-index-2020-the-ten-countries-most-impacted-by-terrorism/> (2021, September, 20).

${ }^{3}$ European Commission (2021). Changing security paradigm <https://knowledge4policy.ec.europa.eu/changingsecurity-paradigm_en> (2021, September, 19).
} 
the capabilities of the darknet to gain access to modern weapons. Unfortunately, the issue of resolving this problem remains open and continues to be investigated by experts ${ }^{1}$.

An important factor influencing the change in the security paradigm is the desire of states in the face of growing instability and uncertainty in world development to increase their own capabilities of defense and defense against internal and external threats to the national security system. This, in turn, leads to a number of steps that significantly change the balance of power in international relations. First, among the trends, experts note an increase in total spending on the military sphere. Thus, the largest growth in the last two years took place in countries such as China, Turkey and Saudi Arabia, and the five countries of the world - the United States, China, Saudi Arabia, India and France. These countries account over 60\% of world military spending ${ }^{2}$. This trend in the face of rising uncertainty and conflict in the world will continue to grow ${ }^{3}$. Therefore, it is projected that by 2030 the world's military arsenals may double, and the military spending of the Asia-Pacific region alone will exceed that of North America (for example, India plans to increase defense spending to $\$ 654$ billion by 2045 , which will exceed similar costs of all EU countries) $)^{4}$.

Secondly, the volume of the world armaments market is increasing, and the main importers are the countries of Asia, Oceania and the Middle East. Already in 2019, the five largest weapon exporters accounted for $74 \%$ of total weapon exports - the United States (33\%), Russia (23\%), China (6.2\%), France $(6 \%)$ and Germany (5.6\%). The largest importers are India and the Middle East - Saudi Arabia, Qatar, Egypt, the UAE, which are trying to buy weapons from various suppliers to reduce dependence on other countries in security and defense, including the United States ${ }^{5}$. Third, there is the change in the balance of power due to the continued increasing in military power. For example, it is predicted that by 2030 the most powerful in the world will be the armed forces of the United States, China, Russia, France and India ${ }^{6}$. The most significant pace is increasing the military and technical superiority of China, which by 2035 plans to completely modernize the armed forces and reach maximum power by $2050^{7}$. The realization of such ambitious goals is planned due to the introduction of modern innovative scientific and technological achievements in the military sphere (high-tech weapons, modern aerospace equipment, robotics, artificial intelligence, quantum technologies, etc. $)^{8}$. In addition, as China is a powerful geopolitical actor and actively

\footnotetext{
${ }^{1}$ Paoli, G. P., Aldridge, J., Ryan, N., Warnes, R. (2017). Behind the curtain. The illicit trade of firearms, explosives and ammunition on the dark web. RAND Corporation <https:/www.rand.org/content/dam/rand/pubs/research_reports/ RR2000/RR2091/RAND_RR2091.pdf> (2021, September, 20).

${ }^{2}$ European Commission (2021). Changing security paradigm <https://knowledge4policy.ec.europa.eu/changingsecurity-paradigm_en> (2021, September, 19).

${ }^{3}$ SIPRI (2019). Military expenditure by region in constant US dollars <https://www.sipri.org/sites/default/files/ Data\%20for\%20world\%20regions\%20from\%201988\%E2\%80\%932018\%20\%28pdf\%29.pdf> (2021, September, 19); Tian, N., Fleurant, A., Kuimova, A, Wezeman, P.D., Wezeman S.T. (2019). Trends In World Military Expenditure. SIPRI <https://sipri.org/sites/default/files/2019-04/fs_1904_milex_2018_0.pdf> (2021, September, 20).

${ }^{4}$ European Commission (2021). Changing security paradigm <https://knowledge4policy.ec.europa.eu/changingsecurity-paradigm_en> (2021, September, 19).

${ }^{5}$ SIPRI (2017). Рост объёма поставок вооружений обусловлен высоким спросом на Ближнем Востоке и в Азии. Press release EMBARGO <https://www.sipri.org/sites/default/files/AT-Press-Release-RUS.pdf> (2021, September, 20); SIPRI (2017). Increase in arms transfers driven by demand in the Middle East and Asia <https://www.sipri.org/media/press-release/2017/increase-arms-transfers-driven-demand-middle-east-and-asia-says-sipri> (2021, September, 21).

${ }^{6}$ Farley, R. (2018). In 2030, These 5 Nations Will Have the World's Most Powerful Armies on the Planet.

Center for the National Interest <https://nationalinterest.org/blog/the-buzz/2030-these-5-nations-will-have-the-worldsmost-powerful-25074> (2021, September,21).

${ }^{7}$ Meia Nouwens (2018). China's military power is growing faster than you think. IISS

<https://www.iiss.org/blogs/analysis/2018/02/china-military-faster> (2021, September, 21).

${ }^{8}$ Net Politics (2018). Why Does Everyone Hate Made in China 2025? Council on Foreign Relations <https://www.cfr.org/blog/why-does-everyone-hate-made-china-2025> (2021, September, 21); Knight, W. (2017). China Plans to Use Artificial Intelligence to Gain Global Economic Dominance by 2030. The country's government has announced a scheme to surpass Western nations and shape the future of AI. MIT Technology Review <https://www.technologyreview.com/2017/07/21/150379/china-plans-to-use-artificial-intelligence-to-gain-globaleconomic-dominance-by-2030> (2021, September, 21); Hui, L. (2018). China's "Micius" completes intercontinental quantum key distribution. Xinhua <http://www.xinhuanet.com/english/2018-01/22/c_136915204.htm> (2021, September, 21).
} 
involved in shaping the modern international security system, further increasing of military power can lead to getting of the Chinese high-tech military technology to the unfriendly countries or other actors that threaten the global peacekeeping system and stability ${ }^{1}$.

Conclusion. The nature and pace of modern information and scientific and technological development leads to addressing the problem of contradictory consequences of this process for the existing global system of peace and security. According to the analysis, the vast majority of technological advances, which now lead to significant positive changes in the field of economy, public administration or social development, have a dual nature of use, which significantly reduces the level of trust to them. Thus, achievements in robotics, artificial intelligence, additive manufacturing can be used to enhance the combat effectiveness of the armed forces of hostile states, through the expansion of the global network and the emergence of the so-called darknet, become available to terrorist and criminal groups in biotechnology and genetic engineering. The formation of cyberphysical systems leads to the gradual blurring of the boundaries between the cybernetic and physical worlds, and hence the interpenetration of threats that are characteristic of one of the dimensions. In addition, today, in the conditions of deepening geopolitical confrontation between the leading actors of international relations, there is intensifying tendency to significant technological modernization of the armed forces and increasing of the defense potential for protection against external threats. In these circumstances, the problem of revision of security paradigm is very urgent and needs rethinking, taking into account the realities of modern challenges and threats which humanity is facing. The development of a new security paradigm will not only take into account the realities of the modern world, but also create conditions for its progressive development.

\section{References:}

1. BBC (2012). Drones: What are they and how do they work? <https://www.bbc.com/news/world-south-asia-10713898> (2021, September, 19). [in English].

2. Charles, A. (2013). Google Glass: is it a threat to our privacy? Guardian <https://www.theguardian.com/technology/2013/mar/06/google-glass-threat-to-our-privacy> (2017, September, 18). [in English].

3. Chen, S. (2017). Chinese Satellite Relays a Quantum Signal Between Cities. WIRED

<https://www.wired.com/story/chinese-satellite-relays-a-quantum-signal-between-cities/>

(2021, September, 19). [in English].

4. Christopher, D., Christopher, G., Dalnoki-Veress, F., Pomper, M., Shaw, R. (2019). WMD Capabilities Enabled by Additive Manufacturing. NDS Report 1908. James Martin Center for Nonproliferation Studies <https://www.nonproliferation.org/wp-content/uploads/2019/09/NDS_Report_1908_WMD_AM_2019.pdf> (2021, September,19). [in English].

5. Department of Defense (2012). Autonomy in Weapon Systems. Directive. Number 3000.09 <https://www.hsdl.org/?view\&did=726163> (2021, September, 19). [in English].

6. European Commission (2021). Changing security paradigm <https://knowledge4policy.ec.europa.eu/ changing-security-paradigm_en> (2021, September, 19). [in English].

7. Farley, R. (2018). In 2030, These 5 Nations Will Have the World's Most Powerful Armies on the Planet. Center for the National Interest < https://nationalinterest.org/blog/the-buzz/2030-these-5-nations-will-havethe-worlds-most-powerful-25074> (2021, September,21). [in English].

8. Fernandez, E. (2019). Soon, People May Be Able To Use 3D Printers To Build Weapons Of Mass Destruction Forbes <https://www.forbes.com/sites/fernandezelizabeth/2019/09/17/soon-people-may-be-able-to-use-3dprinters-to-build-weapons-of-mass-destruction/?sh=12dfb0ee6c92> (2021, September, 19). [in English].

9. Global Peace Index 2020. Measuring Peace In A Complex World (Institute for Economics \& Peace) https://www.visionofhumanity.org/wp-content/uploads/2020/10/GPI_2020_web.pdf> (2021, September, 20). [in English].

10. Harrison, T., Johnson, K., Roberts, T.G. (2019). Space Threat Assessment 2019. A Report of The CSIS Aerospace Security Project. The Aerospace Security Project <https://aerospace.csis.org/wp-content/uploads/2019/04/ SpaceThreatAssessment2019-compressed.pdf>, 5. (2021, September, 19). [in English].

11. Hui, L. (2018). China's "Micius" completes intercontinental quantum key distribution. Xinhua <http://www.xinhuanet.com/english/2018-01/22/c_136915204.htm> (2021, September, 21). [in English].

12. Institute for Economics \& Peace (2019). Global Peace Index 2019 Measuring Peace In A Complex World <https://www.visionofhumanity.org/wp-content/uploads/2020/10/GPI-2019web.pdf> (2021, September,20). [in English].

\footnotetext{
${ }^{1}$ European Commission (2021). Changing security paradigm <https://knowledge4policy.ec.europa.eu/changingsecurity-paradigm_en> (2021, September,21).
} 
13. Institute for Economics \& Peace (2020). Global Terrorism Index 2020: The ten countries most impacted by terrorism <https://www.visionofhumanity.org/global-terrorism-index-2020-the-ten-countries-most-impacted-by-terrorism/> (2021, September, 20). [in English].

14. Knight, W. (2017). China Plans to Use Artificial Intelligence to Gain Global Economic Dominance by 2030. The country's government has announced a scheme to surpass Western nations and shape the future of AI. MIT Technology Review <https://www.technologyreview.com/2017/07/21/150379/china-plans-to-use-artificialintelligence-to-gain-global-economic-dominance-by-2030> (2021, September, 21). [in English].

15. Meia Nouwens (2018). China's military power is growing faster than you think. IISS <https://www.iiss.org/blogs/analysis/2018/02/china-military-faster> (2021, September, 21). [in English].

16. Net Politics (2018). Why Does Everyone Hate Made in China 2025? Council on Foreign Relations <https://www.cfr.org/blog/why-does-everyone-hate-made-china-2025> (2021, September, 21). [in English].

17. Paoli, G. P., Aldridge, J., Ryan, N., Warnes, R. (2017). Behind the curtain. The illicit trade of firearms, explosives and ammunition on the dark web. RAND Corporation <https://www.rand.org/content/dam/rand/pubs/ research_reports/RR2000/RR2091/RAND_RR2091.pdf> (2021, September, 20). [in English].

18. SIPRI (2017). Increase in arms transfers driven by demand in the Middle East and Asia $<$ https://www.sipri.org/media/press-release/2017/increase-arms-transfers-driven-demand-middle-east-and-asiasays-sipri> (2021, September, 21). [in English].

19. SIPRI (2017). Rost obyoma postavok vooruzheniy obuslovlen vysokim sprosom na Blizhnem Vostoke i v Azii [Arms supply growth is driven by strong demand in the Middle East and Asia]. Press release EMBARGO <https://www.sipri.org/sites/default/files/AT-Press-Release-RUS.pdf> (2021, September, 20). [in Russian].

20. SIPRI (2019). Military expenditure by region in constant US dollars <https://www.sipri.org/sites/default/files/Data\%20for\%20world\%20regions\%20from\%201988\%E2\%80\%932018 $\% 20 \% 28$ pdf\%29.pdf> (2021, September, 19). [in English].

21. Tian, N., Fleurant, A., Kuimova, A, Wezeman, P.D., Wezeman S.T. (2019). Trends In World Military Expenditure. SIPRI <https://sipri.org/sites/default/files/2019-04/fs_1904_milex_2018_0.pdf> (2021, September, 20). [in English].

22. UN. General Assembly (1999). Role of science and technology in the context of international security and disarmament <https://digitallibrary.un.org/record/399865> (2021, September, 19). [in English].

23. United Nations (2021). Developments in the field of information and telecommunications in the context of international security <https://www.un.org/disarmament/ict-security/> (2021, September, 16). [in English].

24. Walsh, T. (2019). A.I. Expert, Is Racing to Stop the Killer Robots. The New York Times <https://www.nytimes.com/2019/07/30/science/autonomous-weapons-artificial-intelligence.html?auth= link-dismiss-google1tap> (2021, September, 19). [in English].

25. World Economic Forum (2020). Global Risks Report 2020 <http://www3.weforum.org/>, 61. (2021, September, 16). [in English].

26. Izyumov, D. B., Kondratyuk, Ye. L., Grenchikhin, A. V., Logunov, A. B. (2018) Ispolzovaniye iskusstvennogo intellekta v voprosakh obespecheniya natsionalnoy bezopasnosti SSHA [The use of artificial intelligence in matters of US national security]. Innovatika i ekspertiza [Innovation and expertise], 3 (24), 169. [in Russian].

27. Korelina, O. (2018). V Kitaye sozdayut totalnuyu sistemu raspoznavaniya lits grazhdan. Ona pomozhet lovit prestupnikov i sobirat dannyye na vsekh ostalykh [In China, they create a total system for recognizing the faces of citizens. She will help catch criminals and collect data on everyone else]. Meduza <https://meduza.io/feature/2018/02/11/v-kitae-sozdayut-totalnuyu-sistemu-raspoznavaniya-lits-grazhdan-onapomozhet-lovit-prestupnikov-i-sobirat-dannye-na-vseh-ostalnyh> (2021, September, 18). [in Russian].

28. Schwab, K. (2019). Chetverta promyslova revolyutsiya. Formuyuchy chetvertu promyslovu revolyutsiyu [The fourth industrial revolution. Forming the fourth industrial revolution]. Kharkiv: KSD. [in Ukrainian]. 